www.czasopisma.marszalek.com.pl/pl/10-15804/npw

\author{
ZuZanna KamyKowsKa \\ Uniwersytet Ekonomiczny w Krakowie \\ ORCID: https://orcid.org/0000-0003-4049-4263
}

\title{
Przemiany na chińskim rynku sztuki w latach 1949-2019
}

\section{Transformation of the Chinese Art Market (1949-2019)}

\section{Abstract}

Over the past 70 years, the art market in China has achieved remarkable growth. This rapid development has brought China to the spotlight of the international art world. Initially, state-owned antique stores played a key role in acquiring works of art. It wasn't until the 1980s that professional art galleries began to be opened, and the first auction houses did not appear until the early 1990s. The two largest auction houses: China Guardian (founded in 1993) and Poly Auctions (founded in 2005) occupy the third and fourth place in size of auction houses after Christie and Sotheby's. Currently, Chinese art market has become the second largest in the world. Chinese paintings and works of art are the dominant selling category, and the largest group of buyers are Chinese collectors who perceive art as a way to locate their capital in the country. Due to the active acquisitions of artworks in both domestic and international art markets, Chinese art collectors have gained worldwide attention.

Keywords: Chinese Art Market, Chinese Art, Art Market, Value of Art, Auction Houses

\section{Изменения на китайском арт-рынке в 1949-2019 гг.}

\section{Аннотация}

За последние 70 лет рынок искусства в Китае достиг значительного роста. Это быстрое развитие сделало Китай центром внимания международного мира искусства. 
Первоначально ключевую роль в приобретении произведений искусства играли государственные антикварные магазины. Лишь в 1980-х годах начали открываться профессиональные художественные галереи, а первые аукционные дома появились только в начале 1990-х. Два крупнейших аукционных дома: China Guardian (основан в 1993 году) и Poly Auctions (основан в 2005 году) занимают третье и четвертое место по размеру аукционных домов после Christie и Sotheby's. В настоящее время рынок китайского искусства стал вторым по величине в мире. Китайские картины и произведения искусства являются доминирующей категорией продаж, а самая большая группа покупателей - это китайские коллекционеры, которые воспринимают искусство как способ инвестиции своего капитала в стране. Благодаря активному приобретению произведений искусства как на внутреннем, так и на международном арт-рынках, китайские коллекционеры искусства привлекли внимание всего мира.

Ключевые слова: китайский рынок искусства, китайское искусство, художественный рынок, стоимость произведений искусства, аукционные дома

\section{Wstęp}

Cywilizacja Chin istnieje od ponad 5000 lat. Długa historia zostawiła za sobą znaczącą spuściznę artystyczną. Od momentu powstania chiński rynek sztuki wielokrotnie ulegał przemianom, które odpowiadały transformacjom kultury chińskiej, od praktyczności do kunsztu, od handlu wymiennego do pojawienia się świadomości gospodarki towarowej (Łakomska, 2015, s. 7).

Celem niniejszego artykułu jest przedstawienie chińskiego rynku sztuki w ujęciu historycznym, ze szczególnym uwzględnieniem ostatnich 70. lat, od powstania Chińskiej Republiki Ludowej po dzień dzisiejszy. W artykule zostały wyróżnione poszczególne fazy rozwoju badanego rynku, a także została podjęta próba ujęcia momentów przełomowych oraz najważniejszych segmentów rynku. Przyjętą metodą badawczą jest analiza treści dokumentów, raportów aukcyjnych oraz analiza literatury zarówno angielskojęzycznej, jak i chińskojęzycznej.

\section{Początki handlu sztuką}

Sztuka traktowana jako towar w Chinach po raz pierwszy pojawiła się w okresie późnego neolitu (6000-5500 p.n.e.) (Wang, 2005, s. 295). 
Przeprowadzone wykopaliska archeologiczne ujawniły dużą liczbę ozdób wykonanych z jadeitu na obszarach Chin, na których jadeit naturalnie nie występuje. Odnalezienie jadeitowych ozdób na tych terenach wynikać może nie tylko z grabieży wojennych lub migracji ludności, lecz może być także wynikiem wymiany towarowej. Ponadto w kulturze Dawenkou, kulturze Longshan, kulturze Liangzhu i innych miejscach znaleziono dużą liczbę ozdób wykonanych z jadeitu i agatu, a także fragmenty jadeitowych półfabrykatów oraz narzędzi do produkcji ozdób, które wskazują, że już ok. 4000 lat p.n.e. istniał na nie popyt na rynku ${ }^{1}$. W czasach dynastii Xia, Shang i Zhou po raz pierwszy ustanowiony został status królestwa, w konsekwencji czego pojawiła się królewska etykieta artystyczna, łącząca kunszt sztuki z praktycznymi potrzebami dworu $(\mathrm{Xi}, 2010)^{2}$. Za czasów dynastii Han istniały już podstawowe formy sprzedaży dzieł sztuki, a główną formą sprzedawanej sztuki była kaligrafia (Li, 2017, s. 84).

Wzrost zainteresowania obrotem dzieł sztuki nastąpił w czasach dynastii Tang, za czasów której silna gospodarka i rozwinięte społeczeństwo doprowadziły do wytworzenia klasy nabywców towarów luksusowych ${ }^{3}$. W tym czasie pojawiło się wielu wykwalifikowanych rzemieślników, którzy łączyli się w małe warsztaty rzemieślnicze (Chen, 2013). Za czasów panowania dynastii Song dzieła sztuki cieszyły się szczególnym uznaniem pośród rodziny cesarza i najwyższych urzędników państwowych. Powstawało wiele kolekcji dzieł sztuki, zakładanych przez chińskich uczonych, a do najważniejszych zbiorów zaliczyć należy kolekcję Ouynng Xiu (欧阳修), kolekcję Su Shi (苏 轼), Li Gonglin (李公麟), Wang Shen (王诜) oraz Mi Fu (米䊇) (Eakomska,

${ }^{1}$ Kulturą Dawenkou (大汶口文化 Dàwènkǒu wénhuà) archeolodzy określają społeczność neolityczną zamieszkującą pierwotnie obszar Shandong, istniejącą w latach 4100 p.n.e. do 2600 p.n.e., za: Encyklopedia..., 2000, s. 25; Kultura Longshan (龙山文化 Lóngshān wénhuà) istniała między 2500-1850 p.n.e., zamieszkując obszar centralnego i dolnego biegu Żółtej Rzeki, za: ibidem, s. 26-27; Kulturą Liangzhu (良渚文化 Liángzhǔ wénhuà) istniała między 3400-2250 p.n.e. w delcie rzeki Jangcy. Za: Underhill, 2013, s. 574.

2 Dynastia Xia (夏朝 Xià Cháo), panująca w latach ok. 2070-1600 lat p.n.e., uważana jest za najstarszą dynastię chińską, za: Granet, 1973, s. 29-31. Dynastia Shang (商朝 Shāng Cháo) panowała od ok. 1600 p.n.e. do 1046 p.n.e., za: China Encyclopedia, 2008, s. 17; Dynastia Zhou (周朝 Zhōu Cháo) panująca w latach ok. 1045 do 256 r. p.n.e. była to najdłużej panująca dynastia w historii Chin. Za: Granet, 1973, s. 32-34.

3 Dynastia Tang (唐朝 Táng Cháo), panująca w latach 618-907 n.e., przez badaczy uważana jest za najświetniejszy okres chińskiej kultury. Za: Ebrey et al., 2006, s. 91. 
2015, s. 151). Na szczególną uwagę zasługuje postać cesarza Huizonga ( 徽宗), który dokonał zakrojonej na wielką skalę rekonstrukcji cesarskiej kolekcji dzieł sztuki (Ebrey, 2008, s. 91).W okresie panowania dynastii Ming rynek malarstwa uległ znaczącemu rozwojowi, co jest ściśle związane z dalszym rozwojem gospodarki towarowej miast ${ }^{4}$. Pojawiły się niezależne sklepy z malarstwem i kaligrafią, a co za tym idzie również prywatni kolekcjonerzy (Li, 2017, s. 85). Jak zauważa Yan Cheng, kolekcjonerów sztuki w Chinach można podzielić na kilka typów: osoby kupujące sztukę dla przyjemności, inwestorzy, którzy liczą na wysoką stopę zysku z inwestycji oraz osoby, które kupują sztukę jako legitymizację swojego statusu społecznego (Cheng, 2013, s. 20). Ostatnia grupa przypomina argument poddany przez Bordieu o tym, że burżuazja motywuje swój wzrost polityczny i społeczny wyrafinowanym gustem kulturalnym (Bourdieu, 1984). Kolejny etap rozwoju starożytnego chińskiego rynku malarstwa i kaligrafii przypada na panowanie dynastii Qing 5 .W tym czasie zainteresowanie dziełami sztuki wzrosło na tyle, że powszechne stało się zjawisko fałszowania obrazów i kaligrafii (Li, 2017, s. 86).

W latach 1950-1957, po proklamacji Chińskiej Republiki Ludowej, relacje podaży i popytu na chińskim rynku sztuki były stosunkowo stabilne. Lata 1966-1976 to szczególny okres historyczny, zwany Wielką Proletariacką Rewolucją Kulturalną ${ }^{6}$. Był to ruch społeczno-polityczny, którego inicjatorem był Mao Zedong. Głównym założeniem było odcięcie od historycznej przeszłości i obalenie dawnych autorytetów. Osiągnięciu zamierzonego celu towarzyszyły masowe czystki oraz represje wobec intelektualistów. Dawne dzieła sztuki, zabytki, książki były niszczone, by w ich miejsce wprowadzić nowe, zgodne z doktryną maoistowską. Jednym z założeń rewolucji kulturalnej było zniszczenie tzw. czterech starości (四旧 sijiu), czyli dawnych

${ }^{4}$ Dynastia Ming (明朝 Míng Cháo) panowała w latach 1368-1644. Za: Ebrey et al., 2006, s. 271.

${ }^{5}$ Dynastia Qing (清朝 Qìng cháo), nazywana również dynastią mandżurską, panowała w latach 1644-1912 i była ostatnią dynastią cesarską Chin. Za: Wang, 2012.

${ }^{6}$ Rewolucja kulturalna rozpoczęła się 16 maja 1966 roku podczas posiedzenia Biura Politycznego KC KPCh, kiedy to została utworzona Grupa do spraw Rewolucji Kulturalnej. Ruch został oficjalnie zakończony w 1969 roku przez Mao Zedonga, jednak faktycznie trwał do aresztowania tzw. Bandy Czworga w 1976 roku. 
tradycji, myślenia, obyczajów i nawyków (Jiang, 2000, s. 179). W tym okresie historycznym rynek sztuki praktycznie przestał istnieć.

Przeprowadzone w latach 80. XX wieku reformy Deng Xiaopinga doprowadziły do otwarcia Chin na świat i rozwoju chińskiego rynku sztuki (Qin, 2005). Rozwój ten można podzielić na cztery fazy: okres przejściowy (1980-1989), okres wzrostu (1990-2008), okres dostosowawczy (2009-2011) i okres kompleksowej budowy (2011-2019) (Qin, 2005).

\section{Okres przejściowy. Rynek antyków}

Okres przejściowy przypada na lata 1980-1990, kiedy to po otwarciu Chin działalność rozpoczął chiński ruch emancypacyjny, który doprowadził do zniesienia ograniczeń ideologicznych i ponownego zainteresowania inwestowaniem w dzieła sztuki (Qin, 2005). Pierwszym przejawem regulacji rynku sztuki było wyznaczenie miejsc handlu antykami i dziełami sztuki, np. Da Pu Lu (打浦路) w Szanghaju (Li, 2017, s. 87). W tym okresie nie było jeszcze takiej koncepcji, jak rynek sztuki w dzisiejszym tego słowa znaczeniu, nie było też nowoczesnych galerii, targów sztuki i aukcji sztuki, jak również popularnych obecnie targów z antykami. Dzieła tradycyjnych malarni oraz wytwory rękodzielnicze dystrybuowane były głównie w hotelach. Sklepy z rękodziełem zajmowały się handlem antykami i rzemiosłem ${ }^{7}$.

Historycznym punktem zwrotnym, który zaważył na dalszym rozwoju chińskiego rynku sztuki, była wystawa Star Art (星星美展) z 27 września 1979 roku (Doran, 1993, s. 19). Wystawa The Star Art Group (星星), składająca się z dzieł artystów awangardowych, została wystawiona nielegalnie na balustradzie Chińskiej Narodowej Galerii Sztuki, po tym jak artystom odmówiono przestrzeni wystawienniczej ${ }^{8}$. Po wystawie członek grupy, malarz Yan Li, po

7 W 1993 roku Duo Yun Xuan przeprowadził pierwszą w Chinach aukcję dzieł sztuki, która obejmowała 156 pozycji, a łączna sprzedaż wyniosła 1,07 mln USD. Za: Wu Kenjia, 2019.

8 Star Painting Group to pierwsza awangardowa grupa artystyczna, która pojawiła się w Pekinie pod koniec lat 70. Głównym założeniem ideologicznym grupy było dążenie do wolności i wyrażania siebie. Ich prace noszą znamiona eksperymentalizmu w zachodnim stylu modernistycznym, a ich twórczość podważała chińskie koncepcje estetyczne oraz au- 
raz pierwszy sprzedał swoją pracę, a obraz ten uznany został za pierwszy obraz sztuki współczesnej, który wszedł na rynek po reformach i otwarciu Chin.

\section{Okres wzrostu. Domy aukcyjne, prywatne galerie sztuki, dzielnice artystyczne}

Początek lat 90. XX wieku to okres wzrostu znaczenia chińskiego rynku sztuki. Pierwszym przejawem był intensywny rozwój rynku antyków w latach 90. XX wieku, m.in. targowisk ludowych, takich jak Panjiayuan (潘 家园) w Pekinie czy ulica Fangbanglu (方浜路) w Szanghaju (Yumeng Li, 2017, s. 86). W 1995 roku zostało otwarte Beijing Antique City, które stało się symbolem chińskiego przemysłu antykwarycznego i do dziś przewodzi rozwojowi chińskiego przemysłu antyków (Běijīng..., 2011, s. 40-41).

W 1991 roku Chińska Narodowa Konferencja Kulturalna zdecydowała dopuścić do otwarcia pierwszych domów aukcyjnych na terenie Chin kontynentalnych. Decyzja podyktowana była chęcią ukrócenia nielegalnych aukcji sztuki oraz wprowadzenia mechanizmów regulacji rynkowej. Pierwsza aukcja sztuki na terenie Chińskiej Republiki Ludowej miała miejsce w 1992 roku (Davis, 2004, s. 31). Rok później w Pekinie został otwarty China Guardian, pierwszy chiński dom aukcyjny ${ }^{9}$.W 1994 roku został otwarty kolejny dom aukcyjny Beijing Hanhai Art Auction Co. Ltd., znany obecnie jako Beijing Hanhai Auction Co. Ltd., którego działalność skoncentrowana jest na sprzedaży antyków i reliktów kulturowych oraz promocji i podnoszeniu statusu sztuki chińskiej na świecie ${ }^{10}$. Kolejne domy aukcyjne zostały otwarte w Szanghaju, były to m.in. Duo Yun Xuan Art Auctioneers ufundowany w 1992 roku oraz Shanghaj New Century Auction (Davis, 2004, s. 31).

W latach 90. XX wieku Chiny zaczęły wzmacniać nadzór nad rynkiem sztuki. Sformułowany został szereg przepisów i rozporządzeń dotyczących regulacji rynku sztuki (Chen, 2013). Do najważniejszych dokumentów należą:

torytet polityczny. Star Painting Group zorganizowało jeszcze dwie wystawy sztuki w latach 1979 i 1980, które wywołały wówczas ogromne reperkusje społeczne.

9 Opracowanie własne na podstawie danych zawartych na stronie internetowej: http:// www.cguardian.com/en/gyjd/gsjs/index.shtml.

10 Opracowanie własne na podstawie danych zawartych na stronie internetowej: http:// hanhai.net/About.php. 
ogłoszona w 1990 roku Ustawa o prawie autorskim Chińskiej Republiki Ludowej (中华人民共和国著作权法), ogłoszona w 1994 roku Ustawa dotycząca środków administracyjnych do zarządzania sztuką (美术品经营管 理办法) oraz wdrożona w 1997 roku Ustawa o aukcjach Chińskiej Republiki Ludowej (中华人民共和国拍卖法). Wprowadzenie powyższych regulacji stopniowo poprawiło otoczenie prawne rynku sztuki ${ }^{11}$. Szybki rozwój branży aukcyjnej doprowadził do utworzenia w 1995 roku China Association of Auctioneers (CAA), pierwszego i jedynego stowarzyszenia branży aukcyjnej w Chinach. Głównym zadaniem CAA jest administrowanie prowadzonych aukcji, regulacja i nadzór nad aukcjami zgodnie z ustawą o Aukcjach Chińskiej Republiki Ludowej, koordynację polityki aukcyjnej, promocję oraz usługi doradcze i rzeczoznawcze ${ }^{12}$. CAA odpowiedzialne jest za coroczne raporty aukcyjne oraz sprawuje nadzór nad bezpieczeństwem transakcji.

The Red Gate Gallery (红门画廊), jedna z pierwszych w Chinach prywatnych galerii sztuki, została otwarta w 1991 roku w Pekinie. Założyciel galerii Brian Wallace swoje zainteresowania współczesną sztuką Chin tłumaczy następująco: „Mając do wyboru menu opcji stylistycznych i technicznych, artyści współczesnych Chin mogą z nieokiełznaną kreatywną energią reagować na otaczające ich zmiany"13. W 1996 roku naprzeciwko Wschodniej Bramy Zakazanego Miasta została otwarta Courtyard Gallery (四合苑), ufundowana przez Handela Lee, która za główny cel stawiała sobie przybliżenie awangardowej sztuki Chin międzynarodowej publiczności (Davis, 2004, s. 30). Tym, co wyróżniało kierowaną przez kuratorkę Karen Smith Courtyard Gallery, była długofalowa strategia nastawiona na cele komercyjne (Engström, 2011). Podobne galerie zostały otwarte w innych dużych ośrodkach miejskich. W Szanghaju w 1991 roku szwajcarski galerzysta Lorenz Helbling otworzył ShangArt, czyli pierwszą galerię całkowicie skoncentrowaną na chińskiej awangardzie. W Szanghaju w 1998 roku została

11 Opracowanie własne na podstawie danych zawartych na stronie internetowej: http:// www.npc.gov.cn/wxzl/gongbao/1990-09/07/content_1479238.htm, http://www. gov. cn/ gongbao/content/2016/content_5070760.htm oraz http://www.npc.gov.cn/wxzl/wxzl/200012/05/content_4664.htm.

12 Opracowanie własne na podstawie danych zawartych na stronie internetowej: http:// www.caa123.org.cn/frontNcShowIntroAction.do? method=showNewsByID\&ID=103.

13 Tłumaczenie własne na podstawie: https://www.redgategallery.com/AboutUs. 
otwarta MediaArt, czyli pierwsza w Chinach galeria zajmująca się jedynie instalacjami artystycznymi oraz sztuką nowych mediów (Davis, 2004, s. 30). Warto zauważyć, że wszystkie prywatne galerie sztuki w Chinach w latach 90. otwarte zostały przez obcokrajowców.

Po 2000 roku krajowe galerie sztuki i domy aukcyjne zaczęły zakładać oddziały regionalne oraz rozpoczęły fuzje i sojusze między przedsiębiorstwami w celu wzmocnienia ich konkurencyjności. Firmy i muzea stały się nabywcami obiektów o wysokim poziomie cen i wielokrotnie ustanawiały rekordy cenowe transakcji (Chen, 2013). Według niepełnych statystyk całkowity obrót krajowych aukcji sztuki przed 2002 rokiem wynosił zaledwie kilkadziesiąt mln CNY, a całkowity obrót w 2002 roku wyniósł 400-500 mln RMB. W 2003 roku całkowity obrót wyniósł 2 mld RMB, by w 2004 roku podwoić tę liczbę. Wiosną 2005 roku obrót wyniósł 6,8 mld RMB, a roczna wielkość sprzedaży wyniosła 14,8 mld RMB, a w 2006 roku było to aż 22 mld RMB (Li, 2017, s. 87).

Na początku XXI wieku w Chinach zaczynają powstawać tzw. dzielnice artystyczne. Pierwszą z nich, symbolem nowego zjawiska, jest 798 Art District w Pekinie, oficjalnie otwarta w 2002 roku na terenach dawnej fabryki, która początkowo służyła chińskiej Akademii Sztuk Pięknych CAFA jako przestrzenie magazynowe (Cui, 2014). W 2000 roku dziekan Wydziału Rzeźby CAFA, Sui Jianguo (隋建国), otworzył tam tymczasową pracownię dla studentów i pracowników swojego wydziału, będącą jednocześnie przestrzenią otwartą dla zwiedzających. Otwarcie pierwszego studia artystycznego przyciągnęło kolejnych artystów i inwestorów w sztukę. Do 2003 roku na terenie 798 działało już ponad 30 pracowni artystycznych, wśród których do najważniejszych należały studia: designera Huang Ruia (黄 锐), fotografa Xu Yonga (徐勇), malarza Li Songsonga (李松松) oraz wydawcy Roberta Bernella (Davis, 2004, s. 731). Od 2002 roku na terenie 798 Art District zostały otwarte prywatne galerie sztuki, m.in. Beijing Tokyo Art Projects (BTAP, 北京东京艺术工程), będąca filią Japan's Tokyo Gallery, czy Space Gallery (Davis, 2004, s. 731). Obecnie kompleks stał się jedną z głównych atrakcji turystycznych Pekinu, a rocznie odwiedza go ponad $75 \mathrm{mln}$ ludzi. Podobne dzielnice artystyczne zostały otwarte w innych lokalizacjach. $\mathrm{Na}$ wschodnich przedmieściach Pekinu powstała Songzhuang Art Colony (宋庄艺术区), kolonia artystyczna zrzeszająca chińskich artystów 
awangardowych, obecnie zamieszkiwana przez ok. 2 tys. -4 tys. artystów (Berenstein, 2010). Głównym założeniem Songzhuang Art Colony był powrót do prostoty i natury. Podobne cele stawiali sobie artyści zamieszkujący założoną przez Ai Weiweia dzielnicę artystyczną Caochangdi (草场地), której nazwę można tłumaczyć dosłownie jako „pastwisko”"14. Sam artysta otworzył tutaj własną pracownię - 258 Fake Design Studio, która działała do roku 2018, kiedy chińskie władze bez uprzedzenia zrównały budynek z ziemią ${ }^{15}$. Podobny los spotkał pekiński Huantie Art District oraz Roma Lake Art District, które zostały wyburzone w lipcu 2019 roku ${ }^{16}$.W Szanghaju pierwszą dzielnicą artystyczną została M50 Creative Park (莫干山路50号), zapoczątkowana przez chińskiego twórcę awangardowego Xue Songa (薛 松 $)^{17}$. W 2003 roku w Szanghaju odbył się pierwszy Wiosenny Salon Sztuki, w którym uczestniczyły instytucje artystyczne, a w 2004 roku w Pekinie odbyły się pierwsze wystawy w China International Gallery (Li, 2017, s. 87).

\section{Okres dostosowawczy. Innowacje na chińskim rynku sztuki}

Dynamiczny rozwój rynku sztuki w Chinach trwał do 2008 roku, a łączna wartość sprzedaży w sektorze aukcyjnym od 2001 roku wzrosła o ponad 500 proc. Biorąc pod uwagę globalny kryzys finansowy i spadek sprzedaży

14 Ai Weiwei (ur. 1957) - chiński artysta awangardowy, kurator i aktywista. Współautor projektu Stadionu Narodowego w Pekinie, a także słynnej ekspozycji Sunflower Seeds w Tate Modern w Londynie w 2010 roku. W 2008 roku zaangażował się w dochodzenie w sprawie ofiar trzęsienia ziemi w prowincji Syczuan (四川), a wyniki swoich ustaleń publikował na swoim blogu oraz mediach społecznościowych. Efektem społecznej aktywności Ai Weiweia były liczne represje władz chińskich, m.in. uniemożliwienie otwarcia nowego studia w Szanghaju (ostatecznie zburzonego przez władze w 2011 roku), liczne zatrzymania paszportu, a nawet kara więzienia. Mimo ogromnej popularności poza granicami Chin, nazwisko Ai Weiweia zostało praktycznie wymazane $\mathrm{z}$ chińskich stron internetowych oraz publikacji: https://wyborcza.pl/1,75399,9831891,Ai_Weiweiowi_nie_wolno_opuszczac_Pekinu_bez_specjalnego.html.

15 Opracowanie własne na podstawie danych zawartych na stronie internetowej: https://www.npr.org/2018/08/04/635654200/ai-wei-weis-beijing-studio-destroyed-by-chinese -authorities/? $\mathrm{t}=1581166130420$.

16 Opracowanie własne na podstawie danych zawartych na stronie: https://www.theartnewspaper.com/news/beijing-arts-districts-evicted.

17 Opracowanie własne na podstawie danych zawartych na stronie internetowej: http:// $\mathrm{m} 50 . \mathrm{cn} / \mathrm{zh} /$ about-us/. 
dzieł sztuki na wiodących rynkach światowych, tendencja sprzedażowa była tym bardziej znamienna. W latach 2007-2011 na chińskim rynku sztuki nastąpiły znaczące zmiany. Pojawiło się wiele innowacji związanych z rynkiem, w tym indeksów sztuki, funduszy sztuki, funduszy powierniczych i prywatnych placówek finansujących sztukę. W 2007 roku powstało Centrum Analiz i Badań Rynku Sztuki AMRC, będące pierwszą profesjonalną, krajową instytucją zajmującą się analizą branży sztuki. Dodatkowo AMRC stworzyło też pierwszą platformę badań i rozwoju finansowania rynku sztuki w Chinach ${ }^{18}$. Wprowadzony został również indeks Yachang (AAMI), czyli system indeksu rynku sztuki nadzorowany przez Artron Monitoring Center (AMMA), który odzwierciedla zmiany ceny rynku sztuki i jego statusu operacyjnego. Wykorzystuje bazę danych chińskiej sztuki Yachang jako podstawę statystyczną, naukowo wybiera reprezentatywne próby. Obecnie indeks Yachang stał się barometrem chińskiego rynku sztuki, niezbędnym narzędziem odniesienia dla kolekcjonerów sztuki ${ }^{19}$. Chiński rynek sztuki, zdominowany dotąd przez kolekcjonerów kaligrafii, stał się rynkiem inwestycyjnym. W 2011 roku łączna sprzedaż osiągnęła 9,3 mld USD (62,848 mld RMB), co stanowiło 5-krotny wzrost w stosunku do roku 2008 (McAndrew, 2014, s. 7). W tym samym roku padł również rekord sprzedaży drogich dzieł sztuki - sprzedano aż 23 obiekty o jednostkowej wartości ok. 15,5 mln USD (dla porównania rok później w 2012 roku sprzedano ich już tylko 5) (McAndrew, 2014, s. 8).

\section{Okres kompleksowej budowy}

Po 2012 roku dotąd szybko rozwijający się chiński rynek sztuki wszedł w tak zwany „okres kompleksowej budowy”. Spadek wyników finansowych w 2012 roku w porównaniu do poprzednich lat nazywany był „ochłodzeniem popularności chińskiego rynku sztuki”, jednak bardziej odpowiednim terminem wydaje się być „powrót do racjonalności”. Aktem, który przypieczętował zmianę na chińskim rynku sztuki było certyfikowanie przez CAA pierwszej grupy domów aukcyjnych (na liście znalazły się 44 pozycje), które spełniły

18 Opracowanie własne na podstawie danych zawartych na stronie internetowej: http:// collection.sina.com.cn/pl/amrc/fyvtmxe9255050.html.

19 Opracowanie własne na podstawie danych zawartych na stronie internetowej: https:// amma.artron.net/artronindex.php. 
standard branżowy (McAndrew, 2014, s. 2). W 2013 roku dziesięć najlepszych domów aukcyjnych w Chinach stanowiło aż 58 proc. łącznej wartości sprzedaży. Do najważniejszych przyczyn tak silnego umocowania sektora aukcyjnego zaliczyć należy: spójność i wiarygodność zarówno dzieł sztuki, jak i źródła informacji dostępne w domach aukcyjnych oraz stworzenie platformy do dyskusji na tematy związane $\mathrm{z}$ wartością i autentycznością dzieł sztuki. Pod koniec 2013 roku na terenie Chin kontynentalnych działały już 382 licencjonowane domy aukcyjne, a ich łączna sprzedaż wyniosła 6,1 mld USD (39,8 mld RMB) (McAndrew, 2014, s. 7-8). Pomimo zwiększenia liczby podmiotów działających na rynku wolumen rynku skurczył się o ponad 27 proc. w porównaniu do 2011 roku, a wartość sprzedaży spadła o ponad 3 mld USD. Do najważniejszych przyczyn spowolnienia rynku zaliczyć należy: spowolnienie gospodarcze Chin, regulację rynku kredytowego oraz zmniejszenie liczby wysokiej klasy dobrych prac pojawiających się na rynku (McAndrew, 2014, s. 7).

Spadająca wartość sprzedaży wywołała reakcję chińskich domów aukcyjnych, które wprowadziły do swoich usług możliwość prowadzenia aukcji zamkniętych. Na mocy ustawy o aukcjach z 1996 roku sprzedaż prywatna była nielegalna i do tej pory większość domów aukcyjnych unikała prowadzenia tego typu praktyk aż do 2013 roku, kiedy Poly International zorganizował aż pięć prywatnych wystaw, zakończonych sprzedażą w ramach nowo wprowadzonej usługi VIP (McAndrew, 2014, s. 8). Problem legalności transakcji stanowi duży problem na chińskim rynku sztuki i przez ostatnie kilka lat był przedmiotem ożywionej dyskusji. W raporcie Global Chinese Auction Art Market z 2014 roku szeroko poruszany był temat zjawiska yahui, którym to terminem opisywane jest zjawisko obdarowywania urzędnika państwowego dziełem sztuki bądź falsyfikatem, a następnie odkupienie tego dzieła po znacznie zawyżonej cenie na aukcji (McAndrew, 2015, s. 15). Jak zauważa John Zorbell, na chińskim rynku sztuki zdecydowanie częściej dochodzi do sytuacji, kiedy początkujący artyści wystawiają swoje prace na aukcjach. Praktyka pokazywania dzieł nieznanych artystów na aukcjach sztuki doprowadziła do pojawienia się zjawiska manipulacji cenowej oraz korupcji (Zorbell, 2017, s. 249). Powracający problem falsyfikatów wystawianych na aukcjach odcisnął piętno na chińskim rynku sztuki i przyczynił się do znaczącej liczby nieopłaconych aukcji. W 2016 roku na aukcjach w Chinach 
kontynentalnych opłacono jedynie 58 proc. sprzedanych obiektów, co i tak stanowi czteropunktowy wzrost w stosunku do roku poprzedniego.

Po 2015 roku chiński rynek sztuki wszedł w okres stabilizacji. Szczególnego znaczenia nabrały tzw. prywatne muzea zakładane przez chińskich miliarderów, którzy inwestując w sztukę chcieli przyczynić się do pozostawienia dziedzictwa kulturowego. Do najważniejszych obiektów tego typu zaliczyć należy: Today Art Museum w Pekinie, Yuz Museum w Szanghaju, OCT Contemporary Art Museum w Shenzhen czy Times Museum w Guangzhou ${ }^{20}$. Wzrost sprzedaży chińskiej sztuki i antyków w 2017 roku był $\mathrm{w}$ dużej mierze wspierany przez popyt rozwijającego się sektora prywatnych muzeów w Chinach.

W 2018 roku na skutek wojny handlowej między Stanami Zjednoczonymi i Chinami nastąpiły znaczące spadki na chińskiej giełdzie. Niepewność i napięta sytuacja polityczna między oboma państwami przyniosły większą ostrożność ze strony kolekcjonerów chcących zainwestować w sztukę. W 2018 roku na chińskich aukcjach sprzedano jedynie dziesięć dzieł o wartości powyżej 15 mln USD, co stanowi prawie połowę kwoty sprzedanej w ramach tego przedziału cenowego w 2017 roku. Spadek sprzedaży o 23 proc. w stosunku do roku 2017 odnotowano również w przypadku dzieł powyżej 1,5 mln USD. Tylko dolny segment rynku nie poddał się spadkom sprzedaży - sprzedane prace o wartości poniżej 75500 USD odnotowały nieznaczny wzrost rok do roku. Całkowity wolumen sprzedaży wzrósł o 6 proc., utrzymując ogólną stabilność chińskiego rynku sztuki. Pozytywna tendencja ściśle związana jest ze wzrostem populacji w Chinach (McAndrew, 2019, s. 20).

\section{Podsumowanie}

W ciągu ostatnich siedemdziesięciu lat rynek sztuki w Chinach osiągnął niezwykły wzrost. Pierwsze trzydzieści lat od założeniu Chińskiej Republiki Ludowej w 1949 roku opisać można jako okres stagnacji. Pomimo rewolucji kulturalnej (1966-1976) w Chinach przetrwała ogromna liczba artefaktów kulturowych i antyków. Początkowo kluczową rolę w pozyskiwaniu dzieł

${ }^{20}$ Opracowanie własne na podstawie danych zawartych na stronie Chinese Museums Associaction: http://www.chinamuseum.org.cn/index.html. 
sztuki pełniły państwowe sklepy z antykami. Dopiero w latach 80 . XX wieku zaczęły powstawać profesjonalne galerie sztuki, a pierwsze domy aukcyjne pojawiły się dopiero na początku lat 90 . XX wieku. Obecnie rynek sztuki w Chinach stał się drugim co do wielkości na świecie. Dwa największe domy aukcyjne: China Guardian (założony w 1993 roku) oraz Poly Auctions (założony w 2005 roku) zajmują trzecie i czwarte miejsce pod względem wielkości zaraz po Christie i Sotheby’s. Pierwsze prywatne muzeum non-profit w Chinach zostało założone w 1991 roku, a obecnie ich liczba wynosi prawie 1500. Dominującą kategorią sprzedażową są chińskie obrazy i dzieła sztuki, a największą grupę nabywców stanowią chińscy kolekcjonerzy, którzy postrzegają sztukę jako sposób ulokowania swojego kapitału w kraju.

\section{MGR ZUZANNA KAMYKOWSKA}

Kolegium Ekonomii, Finansów i Prawa

Uniwersytet Ekonomiczny w Krakowie

ul. Rakowicka 27, 31-510 Kraków

zuzanna@sroka.pl

\section{Bibliografia}

Běijīng gǔwàn chéng (2011). Shídài jīngmào, 22.

Berenstien, R. (2010, 09 października). A city where Chinese artists hope to strike gold. The New York Times.

Bourdieu, P. (1984). Language and Symbolic Power. Cambridge, MA: Harvard University Press.

Chen Chen. (2013). Qiăn tán zhōngguó yìshù pǐn shìchăng de lìsȟ̆, xiànzhuàng yŭ fāzhăn tàishì, Wèilái yŭ Fäzhăn. Beijing.

Cheng Yan. (2013). Chinese Art Worlds in China and Abroad: Art Collectors, Institutions and Cultural Identity. M.A. Thesis: Loughborough University.

China Encyclopedia (2008). Beijing: China Intercontinental Press.

Davis, E.L. (red.). (2004). Encyclopedia of Contemporary Chinese Culture. London: Routledge.

Doran, V. (red.). (1993). China's New Art, Post-1989. Hong-Kong: Hanart TZ Gallery.

Ebrey, P.B. (2008). Accumulating Culture. The Collections of Emperor Huizong. Washington, Seattle \& London: University of Washington Press.

Ebrey, P.B., Walthall, A., Palais, J.B. (2006). East Asia: a cultural, social, and political history.

Boston: Houghton Mifflin.

Encyklopedia historyczna świata. (2000). T. III. Kraków: Opres. 
Engström, M.E. (2011). Whatever happened to Courtyard Gallery. Leap Magazine, 9. Pobrane z http://www.leapleapleap.com/2011/06/whatever-happened-to -the-courtyard-gallery/.

Granet, M. (1973). Cywilizacja chińska. Warszawa: PIW.

Jacoby, M. (2009). Powtórzenie i falsyfikat w malarstwie chińskim. Warszawa: Trio.

Jiang Yarong, David, A. (2000). Mao's Children in the New China: Voices from the Red Guard Generation. London: Routledge.

Kaixuan Cui. (2014). Wenya Huang, 798 - sztuka współczesna. Toruń: Wydawnictwo Adam Marszałek.

Kruczkowska, M. (2011, 22 czerwca). Ai Weiweiowi nie wolno opuszczać Pekinu bez specjalnego pozwolenia. Gazeta Wyborcza. Pobrane z: https://wyborcza. pl/1,75399,9831891,Ai_Weiweiowi_nie_wolno_opuszczac_Pekinu_bez_specjalnego.html.

Li Yumeng. (2017). Zhōngguó yìshù pǐn shìchăng sānshí nián biànqiān. China Business Review.

Łakomska, B. (2015). Kolekcjonerstwo w Chinach do XII wieku n.e. Toruń: Polski Instytut Studiów nad Sztuką Świata.

McAndrew, C. (2014). Global Chinese Art Auction Market Report 2013. Artnet.

McAndrew, C. (2015). Global Chinese Art Auction Market Report 2014. Artnet.

McAndrew, C. (2019). Global Chinese Art Auction Market Report 2018. Artnet.

Movius, L. (2019, 11 lipca). Two Beijing art districts abruptly evicted to make way for demolition. Pobrane z: https://www.theartnewspaper.com/news/beijing-arts-districts -evicted.

Qín Chen. (2005). Yishù pǐn tóuzī. Shanghai: Shànghăi Dàxué Chūbănshè.

Prawo autorskie Chińskiej Republiki Ludowej, przyjęte na XV posiedzeniu Stałego Komitetu VII Narodowego Kongresu Ludowego w dniu 7 września 1990 r., ogłoszone rozporządzeniem Przewodniczącego Chińskiej Republiki Ludowej nr 31 z dnia 7 września 1990 r. i obowiązujące od 1 czerwca 1991 r. Pobrane z: http://www.npc. gov.cn/wxzl/gongbao/1990-09/07/content_1479238.htm.

Rozporządzenie Ministerstwa Kultury Chińskiej Republiki Ludowej nr 56, „Eksploatacja i środki zarządzania artykułami” zatwierdzone na posiedzeniu ministerialnym Ministerstwa Kultury w dniu 17 grudnia 2015 r. Pobrane z: http://www.gov.cn/gongbao/ content/2016/content_5070760.htm

Strona internetowa AMMA. Pobrane z: https://amma.artron.net/artronindex.php.

Strona internetowa China Association of Auctioneers. Pobrane z: http://www.caa123.org. $\mathrm{cn} / \mathrm{main} /$ index.jsp.

Strona internetowa China Guardian. Pobrane z: http://www.cguardian.com/en/gyjd/ gsjs/index.shtml.

Strona internetowa China Museum. Pobrane z: http://www.chinamuseum.org.cn/index. html.

Strona internetowa Hanhai. Pobrane z: http://hanhai.net/About.php.

Strona internetowa M50. Pobrane z: http://m50.cn/zh/about-us/.

Strona internetowa Red Gate Gallery. Pobrane z: https://www.redgategallery.com/ AboutUs. 
Underhill, A. (red.). (2013). A Companion to Chinese Archaeology. Chicester: Wiley-Blackwell.

Von Sant, Sh. (2018, 04 sierpnia). Ai Weiwei Responds to Chinese Authorities Destroying His Beijing Studio. Pobrane z: https://www.npr.org/2018/08/04/635654200/ ai-wei-weis-beijing-studio-destroyed-by-chinese-authorities/? $\mathrm{t}=1581166130420$.

Wang Audray. (2012). Chinese Antiquities. An introduction to the Art Market. Handbook in International Art Business. London: Lund Humphries.

Wang Renxiang. (2005). Selected sites. The formation of Chinese Civilization. An archeological Perspective. New Haven and London: Yale University Press.

Wu Kejia (2019). TEFAF Chinese Art Market Report 2019.

Xī Mu. (2010). Zhōngguó yìshù pǐn shìchăng gàilùn. Běijīng: Zhōngguó Shūdiàn Chūbănshè.

Zorbell, J. (2017). Art and The Global Economy. Berkeley: University of California Press. 